\title{
Analysis Implementation System Incident Report With Method Realist Evaluation at Siloam Hospitals Balikpapan 2018
}

\author{
Muhammad Fauzi Saputra ${ }^{1}$, Alimin Maidin ${ }^{1 *}$, Anwar Mallongi $^{2}$, Syamsuddin $^{3}$ \\ ${ }^{1}$ Department of Hospital Management Administration, Faculty of Public Health, Hasanuddin University, Makassar, Indonesia; \\ ${ }^{2}$ Department of Environmental Health, Faculty of Public Health, Hasanuddin University, Makassar, Indonesia; ${ }^{3}$ Department of \\ Accounting, Faculty of Economy and Business, Hasanuddin University, Makassar, Indonesia
}

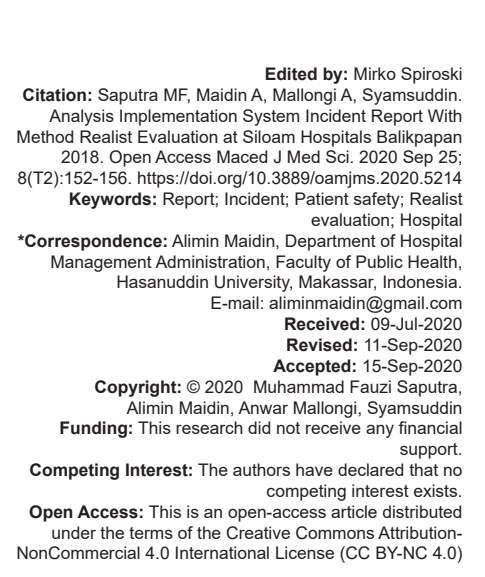

Abstract

BACKGROUND: According to Permenkes No. 11 Tahun 2017, patient safety incidents are any unintended or unexpected incident which could have, or did, lead to harm that could be prevented to patient. Incident reporting system which designed to obtain information about patient safety is used for individual and organization learning.

AIM: This study aimed to analyze the increased success of incident report at Siloam Hospitals Balikpapan.

METHODS: Research design which used is qualitative research with the case study research type and the realist evaluation approach

RESULTS: The data collection is done through observation and profound interview to five officers who's in charge of incident reporting process at Siloam Hospitals Balikpapan. The data processing uses content analysis. The result shows that incident reporting system's implementation at Siloam Hospitals Balikpapan which seen from the side of context mechanism outcome has been working well.

CONCLUSION: The conclusion of this research defines that the implementation's success due to incident reporting program is accorded by reporting guide which has been legitimated by hospital's directors, human resources who have been equipped with training about reporting program facilitate the reporting process and Head Quality Risk as responsible division to the incident reporting process has high responsibility to the program.

\section{Introduction}

Hospital is instance that has aim to give treatment to the patient. However, the alteration of hospital administration paradigm; as hospital is instance which has dense in capital, technology, and resource, make hospital is an easy and prone place to contaminated by conflict in the process of giving the service to the public [1].

Since then, the role of management has been calculated to be involved in determining and handling product quality, but in this era of quality assurance, it has begun to be applied not only to the manufacturing industry but also to the service industry. The service industry or commonly referred to as non-goods is starting to be applied such as in hospitals, health centers, and so on [2]. From time to time, the development of the concept of quality so rapidly must be recognized various programs that have improved the quality of hospital services both in the aspects of input, process, and output or outcome [3]. However, it must be recognized in the quality of service that KTD (unexpected events) often occur which often ends with lawsuits [4].
According to Permenkes No. 11 Tahun 2017, patient safety incidents are any unintended or unexpected incident which did, or could have, lead to the harm that could be prevented to patient. In 2000, Institute of Medicine in "To Err is Human:" Building a Safer Health Care System stated that there are 44.000 up to 98.000 patient's death rate in America's hospital each year which caused by patient safety incident that actually would have been prevented. This incident becomes rare since that number exceeds the death rate which caused by traffic accident and breast cancer [5]. The results of research in Canada shows that $7 \%-12 \%$ of patients experience a safety incident that $30-40 \%$ can actually be prevented [6].

Based on research, Kousgaard [7] which intends to explore the reason for not reporting the patient's safety incident in general practice stated that the cause of low reporting rate is time and low effort of hospital to patient's safety incident since hospital's priority is to compete one another so that formal, comprehensive, and systematic reporting is quite difficult to realize in general practice [8].

Incident reporting system which designed to obtain information about patient's safety is used for 
individual and organization learning. Evaluation result of incident reporting system to patient's safety shows; there has been policy that manages the input process, however, in the policy's implementation, the act has not appropriate [9]. Related to the problem above, the goal of this research is to analyze the increased success of incident report at Siloam Hospitals Balikpapan.

\section{Materials and Methods}

This research is conducted at Siloam Hospital Balikpapan from May 29, 2019, until June 29, 2019. Used research method is qualitative research with the case study research type. Informant in this research consists of the leader of hospital, in this case is CEO (Chief Executive Officer), Ancillary Medical Affair (AMA), Division of Nursing (DON), Head Quality Risk (QR), and Nursing Staff.

Data collection in this research is done by three methods which are profound interview, observation, and document review. Additional instrument as researcher's device in conducting interview is interview's guidelines, tape recorder, filed note, and camera. Obtained data from profound interview are processed manually based on qualitative data processing instruction and the goal of this research. Furthermore, the data are analyzed with content analysis methods and interpreted and served in narrative.

\section{Results}

Profound interview is conducted to five informants which consist of the leader of hospital, in this case is CEO (Chief Executive Officer), Ancillary Medical Affair (AMA), Division of Nursing (DON), Head Quality Risk (QR), and Nursing Staff, guided by interview's guidelines which have been arranged before.

\section{Context}

According to observation's result and profound interview, informant narrated about the suitability of policy that manages the incident report.

"There is a decree for the program's policy. Later you can ask my secretary for seeing it." (012/ SK-DIR/SHBP-IR/XII/2016)" (I1, 51 years old).

Through the informant's statement about the information technology could be shown that majority of the informant have been known which officers who could undertake the report incident through the Q-pulse program.
"All of the officers in Siloam Hospital (could access the program), because this reporting program could be accessed by all the elements (of this hospital), not only the medical officer. The non-medical officer could also access the program, as long as they have the account." (I1, 51 years old).

Informant's statement about communication could be known that socialization has been conducted to all of the staff before the incident report's implementation. This is the following answer which obtained by the informant;

"Yes. There is a socialization before exposing the program to the exposed staff because we have done meetings with the board of directors for the program to be run. Later on, the division who's responsible about this socialization to the staff is medical manager and head nurse.' (I1, 51 years old)

Informant's statement about bureaucracy's structure could be known that there is responsible division to incident report program.

"Yes, (the responsible division is) head quality risk" (I1, 51 years old)"

Informant's statement about the bureaucracy's structure could be known that the policy of the program's implementation could be passed down in stages start from CEO, to head quality risk and will be socialized to implementer staff.

\section{Mechanism}

According to the observation's result and interview, it could be known that head quality risk is in charge of receiving all reports which enter the Q-pulse program. The program's display for head quality risk's is different with the program's display for implementer staff. Furthermore, head quality risk will cross-check the application form which filled in by the reporting officer about the suitability. Reporting process has become easier, because it is no longer done manually but is already using Q-pulse application program. As in the process, start from opening the application then logging in through reporting officer's account. Next, choose the new folder to input new incident report. In this folder, could be found a form that must be filled. This form consisted of few category columns that should be filled in which are the hospital's name column, Incident's type (clinic or general), incident report category, location of incident, and date and time of the recording.

Determination process of incident risk rate is done on two ways which are based by the effect of the happened incident and based on reporting guideline of Insiden Keselamatan Pasien (IKP) which arranged by Komite Keselamatan Pasien Rumah Sakit (KKPRS) in 2015. According to observation result and interview, it could be seen that determination process of incident risk rate is conducted after all reports are entering the 
head quality risk's account and will be recapitulated and cross-checked to the suitability of risk rate that accorded by KKPRS. The officer who's conducting the report with different program's display of application program in head quality risk's account, define the risk rate according to available form in the program.

On the last step which is incident solving process, it is undertook by head quality risk, then conduct the meeting to discuss the whole reports and determine the next step with quality manager and head of nurse.

\section{Outcome}

According to the observation and interview, it could be seen that the increased of incident reporting has been happened since the Q-pulse is implemented. The existence of this program helps the reporting process to become easier so the officer's desire is unlimited by the fear of being blamed (no blame culture) and officer's privacy is guaranteed as reporter.

\section{Discussion}

The result shows that incident reporting system's implementation at Siloam Hospital Balikpapan which seen from the side of context-mechanismoutcome has been working well. Implementation of incident reporting system can increase staff interest to reporting every incident so that a reporting culture is formed in Siloam Balikpapan Hospitals.

Based on the Minister of Health Regulation No. 11 Tahun 2017, Pasal 5 stated that there are seven steps toward patient's safety and one of them is developing the reporting system. Implementation of an incident reporting system in a hospital is influenced by several variables that support one another, these variables include policy, resources, communication, bureaucratic structure, and disposition [10]. The research by Iskandar [11] states that the root causes of most common patient safety errors include communication problems, lack of information, human problems, patients dealing with issues, knowledge transfer in organizations, staffing patterns/workflows, technical failures, lack of policies, and procedures.

Implementation of a policy depends on the human resources responsible for implementing the policy. Human resources must be in accordance with the amount and ability. Even though the contents of the policy have been clearly and consistently communicated, if the implementer lacks the resources to implement it, the implementation will not be effective. Human resources must also be able to understand what is implemented, therefore, human resources must get information on how to conduct policies, understand the essence of the consequences of compliance in carrying out the policy [12]. Implementing a patient safety program in a hospital requires the support of all components from the executive level to the hospital manager level [13].

In the incident reporting process, observations were made which compare the hospital's report incident program with reporting guidelines of patient safety incident which that is issued by KKPRS in 2015, incident type determination in incident report program (Q-Pulse) which owned by Siloam Hospital Balikpapan is more specific than KKPRS guideline in 2015 [14].

There are many methods which used to identify the risk, one of them is to develop the incident reporting program. Reporting system will enhance all people in organization to pay attention about danger or potential danger which could occur to patient [15]. Reporting is also important to monitor the prevention of errors so it could encourage the further investigation [16].

According to Hartono [17], perceived ease-ofuse is the degree to which a person believes that using a particular system would be free from effort. User or person who assumes an easy-to-use information system will use the information system and vice versa; if the information system is deemed difficult to use, then none will use the information system [18]. According to profound interview to informant, it could be concluded that perceived ease-of-use in incident reporting program (Q-pulse) which made is not inflate, clear, and easily understood in making the report because it made by the computer, then it could simplify the reporter without writing manually and taking a lot of forms.

After the reporting process, the next step is determination risk process. According to category which has indicated in incident reporting form (Q-pulse), there are four categories from Siloam Accidentally Category (SAC), which are $1=$ extreme risk, $2=$ high risk, $3=$ moderate risk, and 4 = low risk. This determination risk process is actually similar with guidelines in Komite Keselamatan Pasien Rumah Sakit (KKPRS) 2015. Risk level category is explained as; in low-risk level, simple investigation is run for a week at most which done with routine procedure. In moderate-risk level, simple investigation is run for 2 weeks at most, as clinic manager or leader evaluates the effect to cost and risk management. In high-risk level, root cause analysis (RCA) is done for 45 days at most with detail analysis, immediate action, and attention from top management. For last, in extreme risk level, RCA is also done for 45 days at most which needs immediate action and attention from directors.

The third process is problem-solving process. According to profound interview and observation, Head Risk Quality as the actor on solving the report in incident reporting program (Q-pulse) use particular user account so the whole reports which has been reported will send it to Head Quality Risk's account [19]. Furthermore, cross-checked is conducted to each of the report folder based on suitability of procedures in the form and risk level determination which has been filled by the reporter 
[20], [21]. Solving process of incident report technically will be explained as the followings:

1. Open the incident reporting program (Q-pulse).

2. Enter user and password for logging in. For Head Quality Risk specifically; c. choose the inbox for seeing the incident report.

3. Choose the report folder based on registration number and reporter's name.

4. After the display of reporting form has appeared, Head Quality Risk will cross-check the form start from date reporting column, incident title, and reporter's name.

5. Cross-check the incident's type and risk level based on the suitability with the reported accident and the direct effect of incident.

6. Cross-check the accident's description, victim's name, reporter, and witness.

7. Cross-check the incident report's category specifically.

Furthermore, an analyses reporting incident that is reported will be followed up as its process that has been explained in guidelines of Hospital Patient Safety Committee (KKPRS) in 2015 [14]. Incident reporting completion is conducted by Head Quality Risk based on decree from director who is in his occupied position has suitable competence and profession related to healthy cities and also cooperating with healthy city committees in cities.

\section{Recommendation}

Suggestion to the hospital is to provide a complete equipment which in this case is computers as a supporting facility to facilitate the incident reporting process should be separated with the computers which used for administration process at inpatient room.

\section{Conclusion}

The conclusion of this research defines that the implementation's success due to incident reporting program is accorded by reporting guide which has been legitimated by hospital's directors, human resources who have been equipped with training about reporting program facilitate the reporting process and Head Quality Risk as responsible division to the incident reporting process has high responsibility to the program.

\section{References}

1. Manurung JM. Kajian Implementasi mutu dengan pendekatan integrasi six sigma dan TQM melalui penilaian malcolm baldridge di rumah sakit charitas palembang. J Adm Rumah Sakit. 2018;3(2):128-37. https://doi.org/10.33560/.v2i1.40

2. Meo MY. Pengembangan sistem informasi manajemen keperawatan dengan integrated clinical pathway untuk meningkatkan kualitas pelayanan. J Manajemen Keperawatan. 2015;3(1):48-55. https://doi.org/10.32584/jkmk.v3i1.545

3. Sulahyuningsih E, Tamtomo D, Joebagio H. Analysis of patient safety management in committee for quality improvement and patient safety at Sumbawa hospital, West Nusa Tenggara. J Health Policy Manag. 2014;2(2):147-56. https://doi. org/10.26911/thejhpm.2017.02.02.06

4. Rahmi A. Evaluasi Kebijakan Keselamatan Pasien (Patient Safety) pada Perawat di Rumah Sakit Umum (RSU) Anutapura Palu (Tesis). Palu: Universitas Tadulako; 2018. https://doi. org/10.31227/osf.io/f9s5n

5. Harus BD, Sutriningsih A. Pengetahuan perawat tentang keselamatan pasien dengan pelaksanaan prosedur keselamatan pasien rumah sakit (KPRS) di rumah sakit panti Waluya Sawahan Malang. Care. 2015;3(1):25-32. https://doi. org/10.31219/osf.io/bvgqn

6. Forster AJ, Dervin G, Martin JC, Papp S. Improving patient safety through the systematic evaluation of patient outcomes. Can J Surg.2012;55(6):418-25. https://doi.org/10.1503/cjs.007811 PMid:23177520

7. Kousgaard MB, Joensen AS, Thorsen T. Reasons for not reporting patient safety incidents in general practice: A qualitative study. Scand J Prim Health Care. 2012;30(4):199205. https://doi.org/10.3109/02813432.2012.732469 PMid:23113662

8. Suparti S. Action research: Pelaporan insiden keselamatan pasien di IBS RSUP Dr. Soeradji Tirtonegoro Klaten. Indones J Nurs Pract. 2014;1(2):185-98.

9. Tristantia AD. Evaluasi sistem pelaporan insiden keselamatan pasien di rumah sakit. J Adm Kesehatan Indones. 2018;6(2):8394. https://doi.org/10.20473/jaki.v6i2.2018.83-94

10. Budiono S, Sarwiyata TW, Alamsyah A. Pelaksanaan program manajemen pasien dengan risiko jatuh di rumah sakit. J Kedokteran Brawijaya. 2014;28(1):78-83. https://doi. org/10.21776/ub.jkb.2014.028.01.28

11. Iskandar $\mathrm{H}$, Maksum $\mathrm{H}$, Nafisah $\mathrm{N}$. Faktor penyebab penurunan pelaporan insiden keselamatan pasien rumah sakit. J Kedokteran Brawijaya. 2014;28(1):72-7. https://doi. org/10.21776/ub.jkb.2014.028.01.27

12. Wright PM, McMahan GC. Exploring human capital: Putting human back into strategic human resource management. Hum Resour Manag J. 2011;21(2):93-104. https://doi. org/10.1111/j.1748-8583.2010.00165.x

13. Rahayu SB. Pengaruh dimensi staffing terhadap insiden keselamatan pasien berdasarkan agency for healthcare research and quality (AHRQ) di RSU Haji Surabaya. J Adm Kesehatan Indonesia. 2017;5(1):41-51. https://doi. org/10.20473/jaki.v5i1.2017.41-51

14. Kemenkes RI. Komite Keselamatan Pasien Rumah Sakit (KKPRS): Pedoman Pelaporan IKP. Indonesia: Kementrian Kesehatan Republik Indonesia; 2015. https://doi.org/10.20473/ jaki.v6i2.2018.83-94

15. Cintha GL, Suryoputro A, Jati SP. Analisis pelaksanaan identifikasi pasien dalam rangka keselamatan pasien di unit rawat inap rumah sakit umum daerah kota Bekasi. J Kesehatan Masyarakat. 2016;4(4):43-8. https://doi.org/10.25077/jka. v7i0.921

16. Anggraeni D, Azzuhri M. Pengaruh budaya keselamatan pasien terhadap sikap melaporkan insiden pada perawat di instalasi rawat inap rumah sakit tk. II dr. Soepraoen. J Aplikasi Manajemen. 2016;14(2):309-21. https://doi.org/10.18202/ jam23026332.14.2.13 
17. Hartono J. Sistem Informasi Keperilakuan. Yogyakarta: Penerbit Andi; 2007.

18. Juniarti NH, Mudayana AA. Penerapan standar keselamatan pasien di rumah sakit umum Daerah Provinsi Nusa Tenggara Barat. J Kesehatan Poltekkes Ternate. 2018;11(2):93-108. https://doi.org/10.31764//f.v1i2.2542

19. Pagala I, Shaluhiyah Z, Widjasena B. Perilaku kepatuhan perawat melaksanakan SOP terhadap kejadian keselamatan pasien di rumah sakit X Kendari. J Promosi Kesehatan Indones. 2017;12(1):138-49. https://doi.org/10.14710/jpki.12.1.138-149
20. Russeng SS, Saleh LM, Virani D, Latief AW, Mallongi A. The investigation of the lactic acid change among employee of national electrical power plan. Indian $J$ Public Health Res Dev. 2018;9(1):361-5. https://doi. org/10.5958/0976-5506.2018.00067.0

21. Birawida $A B$, Selomo $M$, Mallongi $A$. Potential hazards from hygiene, sanitation and bacterium of refill drinking water at Barrang Lompo island (water and food safety perspective). IOP Conf Ser Earth Environ Sci. 2018;157(1):012034. https://doi. org/10.1088/1755-1315/157/1/012034 